\title{
Implementation of Supply Chain Management (SCM) in pharmaceutical company, general principles and case study
}

\author{
Zoran Nakov ${ }^{1}$, Stevche Acevski ${ }^{2}$, Rubincho Zareski ${ }^{3}$ \\ ${ }^{I}$ Novo Nordisk Pharma DOOEL ,blvd. Oktomvriska Revolucija 18, 1000 Skopje, R. of Macedonia \\ ${ }^{2}$ Alkaloid AD Skopje, blvd Aleksandar Makedonski 12, 1000 Skopje, R. of Macedonia \\ ${ }^{3}$ Faculty of Pharmacy Skopje, str. Mother Tereza 47, 1000 Skopje, R. of Macedonia
}

Received: October 2014; Accepted: December 2014

\begin{abstract}
Supply Chain Management (SCM) in pharmaceutical industry is defined as a "responsible SCM" and its implementation is according to the principles of: business ethics, rights of labor and principles of healthy and safe working environment. Pharmaceutical companies with implemented "responsible SCM" have to use management systems to facilitate continuous improvement in accordance with their working principles. The main purpose of this management system is to ensure the consistency, reliability and continuous improvement of all workflows within an organization. The analyzed case describes the project of European generic pharmaceutical company, which intends to implement best practice SCM operations for five European manufacturing sites and European logistics organizations (active ingredients supply, distribution centers, affiliate customers and third party manufacturers). The main objectives of the project were the creation of the future improved To-Be situation through implementation of new SCM models to the existing To-Day situation.
\end{abstract}

Keywords: Supply chain management (SCM), responsible SCM, implementation, evaluation

\section{Introduction for SCM}

Supply Chain Management (SCM) is defined as systematic and strategic coordination of the traditional business functions and their tactical coordination within the company itself, systematic and strategic coordination of the traditional business functions and their tactical coordination in cooperation with all business partners of the respective company, with one end point long-term improvement of performance of the company (Mentzer et al., 2001). Generally, SCM is a combination of different disciplines such as logistics, transport and distribution as part of the operational management system, marketing, part of the raw material's orders and procurement of information technology. The ultimate objective of SCM is to create co-

\footnotetext{
*lbogdanovska@ff.ukim.edu.mk
}

ordination between all the previously mentioned operations in order to improve performance of a particular company (Peltz, 2008).

Unlike other industries in the pharmaceutical industry SCM is upgraded and implemented as a "responsible SCM". The term of responsibility is due to the fact that the implementation of SCM in the pharmaceutical companies is according with principles of: business ethics; the rights of labor force and principles of healthy and safe working environment (PSCI guidance, 2011). The pharmaceutical industry in the last two decades is faced by continuous changes in terms of testing and sales a new products. The major changes are mandated by the health authorities in the countries were companies produce or sale. Changes that are commonly encountered are: a permanent pressure on prices and tendency of the health authorities for their constant reduction, shortening the defined period of 
patent protection of original drugs and constant pressure from generic or biosimilar companies. Aimed in reducing their expenses, many pharmaceutical companies decide to merge their research and development process. The implementation of SCM systems in pharmaceutical companies is intended towards rationalization the process of planning, production, distribution and storage of the final product before it comes to its final customer/user. The process of rationalization, through the introduction of standard SCM modules and systems in the pharmaceutical companies, on the other hand allows decreasing the cost of the final product, thus increasing its competitiveness compared to other similar products produced by the competitive pharmaceutical companies (Rees, 2011).

The main purpose of the SCM is to ensure the consistency, reliability and continuous improvement of all workflows within an organization. Pharmaceutical companies with implemented responsible SCM should use management systems to facilitate continuous improvement in accordance with their working principles. By this process they ensure market competitiveness, able to meet the specific requirements of certain countries in terms of the area of business ethics, receive respectable relations with representatives of labor/trade unions, believe that these principles are best implemented through continuous improvement approach in everyday work activities, which indirectly leads to increased competitiveness (Cailet, 2011).

The cycle of this management system represented in Fig. 1 contains four separate activities: plan, do, check and action (PSCI guidance, 2011; ISO 14001, 2004).
Implementation of SCM in pharmaceutical companies usually result with transition from market focused strategy to strategy focused on product; emphasis on the possibility of producing a type of derivative products on one place; centralization of production activities in a manufacturing location; closing and reducing the number of unnecessary manufacturing sites; defining the distribution centers and defining the mode of transport of the products/services to selected distribution centers; defining selection's criteria of potential collaborators/companies that are subject to constant change and improvement in accordance with the requirements of the market and in order to maintain the competitive advantage of the company itself (PSCI guidance, 2011).

Major challenges that SCM program in the pharmaceutical companies could face in the future are: long time necessary for thedevelopmentandapprovalofnewpharmaceuticalproducts, need for expansion of the product line and shorter life cycle of the product due to the aggressive approach of generic and non brand manufacturers, continued market pressure for new and innovative pharmaceutical products, continuous increasing need for quality and increasing demands by regulators, more common situations in which there is no possibility of negotiation, overloaded global supply chains: more production facilities, distribution and sales channels and markets and unpredictable business process: the need for continuous technical and scientific advancement and improvement (Rees, 2011).

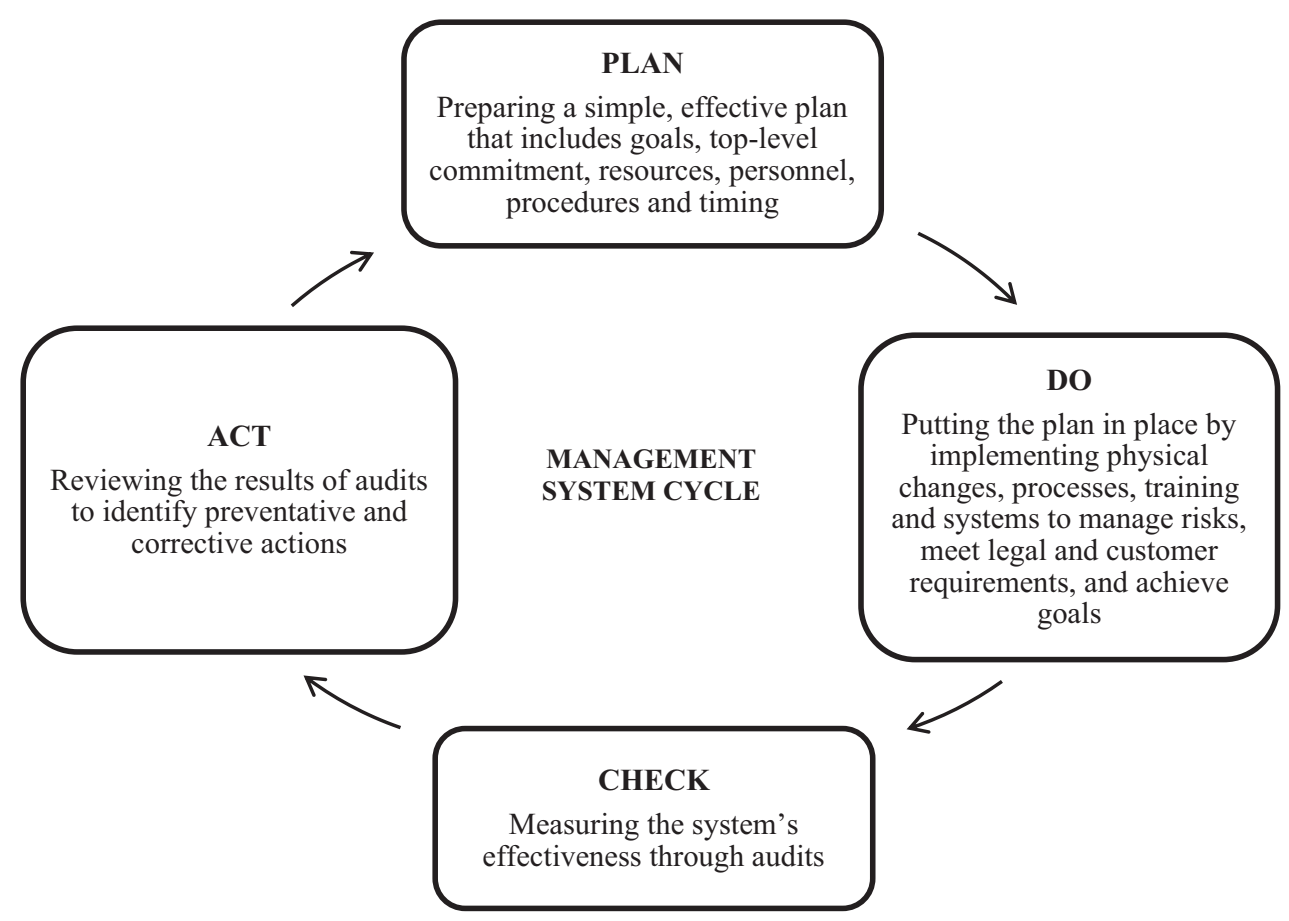

Fig. 1. Pharmaceutical industry principals for Responsible Supply Chain management (adapted from http://www.pharmaceuticalsupplychain.org/downloads/psci_guidance.pdf, 2011). 


\section{Case study of implementation of SCM in pharmaceutical company}

In this case is describing the project of European generic pharmaceutical company, which intends to implement best practice SCM operations for five European manufacturing sites and European logistics organizations (supplier of the active component, distribution centers, affiliate customers and third party manufacturers). This project scope includes SCM planning process, supporting the production planning and detailed scheduling within the pharmaceutical plants as well as the network planning across the company's supply chain to optimally match supply and demand.

The planning process is implemented based on Systems Applications and Products (SAP) in data processing R/3 4.6C and Advanced Planner and Optimizer (APO) 3.1operating system.

The case study focuses on the implementation of the Advanced Planning System (APS) components of SAP APO Production planning (PP)/Detailed scheduling (DS) system as a model to support the production planning and detailed scheduling in the manufacturing plants and SAP APO Supply Network Planning (SNP) to model the supply network planning of the supply chain.

The main results and benefits of the project will be highlighted as well as the major hurdles encountered in the implementation of the SAP APO PP/DS and SNP solution.

\section{Project's objectives}

The main objectives of the project were the creation of future To-Be improve situation across implementation of new models in existing To-Day situation. The need to improve the To-Day situation arose because of no insight into the overall database within the company; not effective and efficient implementation of the manufacturing process; unstable planning process and poor utilization of all available resources; absence of master planning; major ongoing IT costs; no effective and efficient execution of administrative tasks; problems with distribution of raw materials to production locations/final product to end users; recognized and continuous dissatisfaction with end users.

\section{To-Day situation}

The start of the project is described like a To-Day situation. The following list highlights some key aspects of this To-Day situation in analysed company: There are several key aspects of this To-Day situation in analysed company. The first one addresses to $4 \mathrm{SAP} R / 3$ systems (two running R/3 PP, Process Industry (PI), one Business Planning and Control System (BPCS) and one R/2 system. Data integration between the systems was low, data structures not harmonized. The same product existed with several material numbers in different systems. Information sharing as well
Table 1. Evaluation of existing To-Day situation

\begin{tabular}{|c|c|}
\hline \multicolumn{2}{|l|}{ Planning (35\% importance/contribution) } \\
\hline Parametars & Score \\
\hline Time for development of the production cycle & 2 \\
\hline Total cycle time & 2 \\
\hline Time for total money flow & 2 \\
\hline Amount of product and service & 3 \\
\hline Average score & 2.25 \\
\hline \multicolumn{2}{|l|}{ Utilization of resources ( $15 \%$ importance/contribution) } \\
\hline Parametars & Score \\
\hline Interest collaborators for building partnership relations & 3 \\
\hline Time of supply & 2 \\
\hline Reservations for suppliers & 2 \\
\hline Get prices from suppliers & 2 \\
\hline Average score & 2.25 \\
\hline \multicolumn{2}{|l|}{ Production (30\% importance/contribution) } \\
\hline Parametars & Score \\
\hline Cost of production & 2 \\
\hline Capacity utilization & 2 \\
\hline Effective layout of the main planning & 2 \\
\hline Cycle duration of the production process & 2 \\
\hline Level Bearings & 3 \\
\hline Average score & 2.2 \\
\hline
\end{tabular}

Distribution (10\% importance/contribution) Parametars

Score

Delivery time

Number of existing deliveries

Degree of response to urgent deliveries

Total cost of delivery

Average score

Customers satisfaction (10\% importance/contribution) Parametars

Score

Flexible to meet customer requirements partial

Levelat which the client perceived value of the product

as synergies out of a common system were not achievable. The second key aspect is related with the fact that there was no available centralized supply network planning systems, resulting in no central visibility of the supply chain constraints and problems. The next aspect stems from the product planning and detailed scheduling of the manufacturing processes which were performed in various standalone systems and spreadsheets, interfaced with local Enterprise Resource Planning Systems (ERP). This resulted in massive manual planning effort and sub optimal capac- 
ity utilisation. There was no central statistical forecasting system in To-Day environment. In addition the Key Performance Indicators (KPI) was not consistently defined and did not support common targets. At the end the business processes were rather complex, without uniquely defined responsibilities for core planning tasks like materials planning, detailed scheduling and master planning.

\section{Evaluation of To-Day situation}

The evaluation of this To-Day situation was made by scores received from the management team on the basis on analyzed data of planning process, utilization of available resources, manufacturing, distribution and customer satisfaction. The percentages of importance/contribution of the analyzed data in the final score evaluation were defined on the meeting of company top-management and were as follows: planning (35\%), resource utilization (15\%), production process $(30 \%)$, and distribution process and customer satisfaction $(10 \%)$. The evaluation is presented in Table 1 . Total score of the current To-Day situation was 2.34 points (Eq. 1).

\section{$2.25 \cdot 0.35+2.25 \cdot 0.15+2.2 \cdot 0.3+2.5 \cdot 0.1+3.0 \cdot 0.1=\underline{\mathbf{2 . 3 4} \text { points }}$ Eq. 1}

\section{Description of To-Be vision}

To-Be vision was designed to achieve target goals of harmonized processes, data, systems and organizational units in To-Day situation. In To-Be situation 6 ERP sys-

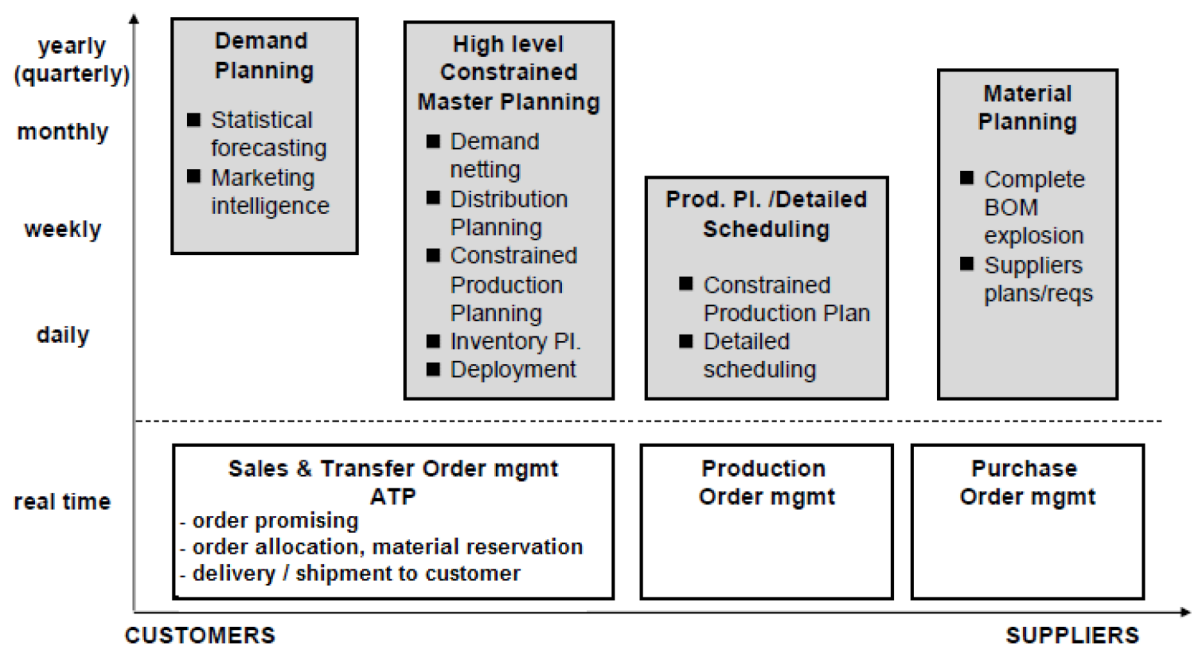

Fig. 2. Simple map of the whole process of planning and implementation of plan (adapted from Caillet, 2008).

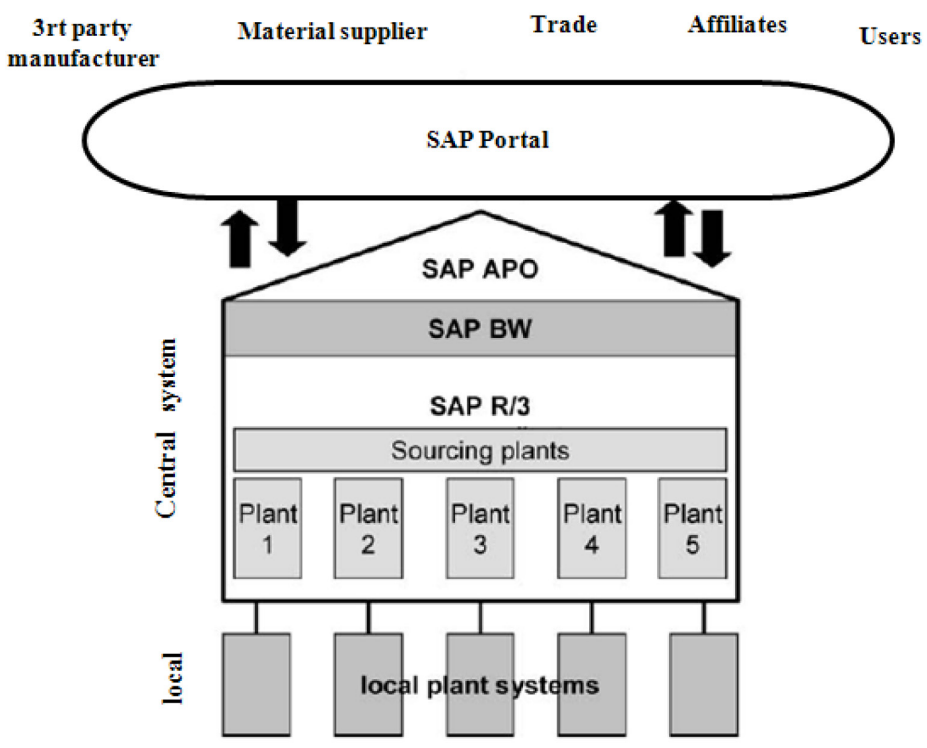

Fig. 3. Schematic presentation of the implemented IT systems. Legend: SAP - Systems Applications and Products, APO Advanced Planner and Optimizer, BW - Business Warehouse (Caillet, T., 2008. SCM in Pharmaceutical Company). 
tems are integrated into a central SAP R/3 system. The level of the entire company was setup a central Advanced Professional Solution System (APS), which represented the entire supply chain system. The major changes in To-Be vision are: change the entire organization from local, function-oriented thinking, to a common European company, sharing the same targets and commitment in true collaboration between the business functions and the supporting IT function; building of an European team to support that challenging vision on both IT and business side; base the project founding on expected benefits, proven by a business case performed before the implementation started; buy-in of all involved stakeholders right from the beginning to propagate the new vision and to support its implementation; setup a collaborative forecasting; visibility of the demand and the supply through the complete network of the supply chain based on one global, constrained master plan; one common detailed scheduling system used by all plants, customized to support local specificities and process inherent constraints; installation of a common European reporting and controlling process, supported by common KPIs; integration of suppliers into the master planning process; implementation of Vendor Managed Inventory (VMI) processes for the major affiliates and customers and transportation planning the vehicle scheduling done by the third party logistics providers. Simplification of these process is presented in Fig. 2.

Table 2. Planning process covered by Enterpise Resource Planning Systems (ERP) and Advanced Professional Solution System (APS) moduls

\begin{aligned} & \hline \hline Enterpise Resource Planning Systems (APS) moduls \\ & \hline Demand planning (DP) SAP APO DP \\ & Master planning (MP) SAP APO SNP \\ & Detailed scheduling (DS) SAP APO PP/DS \\ & Materials requirements planning (MRP) SAP R/3 MRP \\ & Production order management ( POM) SAP R/3 PP-PI \\ & Inventory management (IM) SAP R/3 IM-WM \\ & Procurement direct materilas(PDM) SAP R/3 MM \\ & Master data management (MDM) SAP R/3 MM \\ & Supply chain management (SCC) SAP R/3 Co and \\ & SAP BW \\ & \hline\end{aligned}

Legend: SAP - Systems Applications and Products, APO - Advanced Planner and Optimizer, SNP - Supply Network Planning, PP-DS - Production plainning/Detailed sheduling, MM - Material management, BW - Business Warehouse

Implementation of IT systems in the desired To-Be vision is shown in Figure 3. The figure visualizes the new IT system landscape supporting the To-Be vision of this project. The IT system landscape is based on SAP R/3 4.6C, SAP APO 3.1, the Standard Core Interface (CIF) to integrate R/3 and APO, SAP Business Warehouse (BW) and SAP Enterprise Portals (EP).The central SAP R/3 system covers functionalities provided by the following modules: PP/PI; Materials Management (MM); Sales and Distribu-
Table 3. Evaluation of new To-Be situation

\begin{tabular}{lc}
\hline \multicolumn{2}{c}{ Planning (35\% importance/contribution) } \\
\hline \multicolumn{1}{c}{ Parametars } & Score \\
Time for development of the production cycle & 4 \\
Total cycle time & 3 \\
Time for total money flow & 4 \\
Amount of product and service & 4 \\
Average score & 3.75 \\
\hline
\end{tabular}

Utilization of resources (15\% importance/contribution) Parametars Score

Interest collaborators for building partnership relations $\quad 3.5$

Time of supply 3

Reservations for suppliers 3

Get prices from suppliers $\quad 2.5$

Average score 3

Production (30\% importance/contribution) Parametars Score

Cost of production 3

Capacity utilization 4

Effective layout of the main planning 3

Cycle duration of the production process 3

Level Bearings $\quad 4$

Average score $\quad 3.4$

Distribution (10\% importance/contribution) Parametars Score

Delivery time 3

Number of existing deliveries 3

Degree of response to urgent deliveries 3

Total cost of delivery $\quad 3$

Average score 3

Customers satisfaction (10\% importance/contribution)

Parametars Score

Flexible to meet customer requirements partial $\quad 3.5$

Levelat which the client perceived value of the product $\quad 3.5$

Average score $\quad 3.5$

tion (SD); Quality Management (QM, for batch management, quality inspection lots only); Controlling (CO, for product costing and budget planning), Warehouse Management (WM).

After all relevant functionalities were migrated from the old (local) ERP systems of the plants to the new central ERP system, the remaining local non-ERP systems had to be interfaced to the central environment. These are 
mostly execution control systems, Laboratory Information Management System (LIMS), Material Handling System (MHS) and WH system.

The central R/3 system provides the integration basis for the APO system. From APO, the modules Demand Planning (DM), Supply Network Planning (SNP) and Production Planning/Detailed Scheduling (PP/DS) are used. The process coverage of the APO modules is shown in Fig.3. SAP BW is the foundation of a common reporting and performance measurement system. SAP EP is used to integrate customers into the demand planning process and to enable customers to access sales orders and delivery confirmations. The planning process introduced in Fig. 3 were mapped to the following ERP and APS modules and are presented in Table 2.

\section{Evaluation of new To-Be situation}

Evaluation of a new To-Be situation is made by the same parameters: planning, resource utilization, production, distribution and customer satisfaction (one year after implementation of SCM and creation of new To-Be model) with the same percentage of importance/contribution to the final score evaluation of all measured parameters, reference evaluation of the initial To-Day situation. The eval- uation is presented in Table 3.Total score of the new ToDay situation is 3.43 points (Eq. 2).

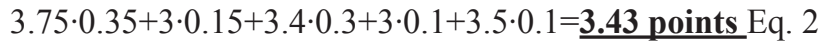

\section{Discussion}

The process which will be evaluated at the implementation of SCM activities depends of company top management assessment, reference the main weaknesses of the current organizational and operational set and which processes are most deserving for the current non reasonable profitability of the company. Selection the KPIs for each process, such as planning, utilization of resources, production, distribution and customer satisfaction is done by a free estimate of the top management of each company. Results without percentage of importance/contribution and with included a percentage of importance /contribution are presented in Table 4 and Table 5, respectively.

The data mentioned above indicated that the implementation of SCM processes allows the highest improvement in the final score in the area of planning, improvement of 1.5 points or $0.52 \%$ points with included percentage of importance/contribution. If we know that the plan-

Table 4 Results without percentage of importance/contribution

\begin{tabular}{cccc}
\hline \hline \multicolumn{2}{c}{ Pharmaceutical company without SCM (To-Day) } & \multicolumn{2}{c}{ Pharmaceutical company with SCM $(T o-B e)$} \\
\hline Analyze the process through predefined KPI & Score & Analyze the process through predefined KPI & Score \\
Planning & 2.25 & Planning & 3.75 \\
Utilization of resources & 2.25 & Utilization of resources & 3.0 \\
Production & 2.2 & Production & 3.4 \\
Distribution & 2.5 & Distribution & 3.0 \\
Customer satisfaction & 3.0 & Customer satisfaction & 3.5 \\
Final score (To-Day) & 12.2 & Final score (To-Be) & 16.6 \\
\hline
\end{tabular}

Table 5. Results with included percentage of importance/contribution

Pharmaceutical company without SCM (To-Day)
Pharmaceutical company with SCM $(\mathrm{To}-\mathrm{Be})$

\begin{tabular}{cccc}
\hline Analyze the process through hpredefined & Score & Analyze the process through predefined KPI & Score \\
KPI & 0.79 & Planning & 1.31 \\
Planning & 0.34 & Utilization of resources & 0.45 \\
Utilization of resources & 0.66 & Production & 1.02 \\
Production & 0.25 & Distribution & 0.3 \\
Distribution & 0.3 & Customer satisfaction & 0.35 \\
Customer satisfaction & 2.34 & Final score (To-Day) & 3.43 \\
Final score (To-Day) & &
\end{tabular}


ning process was given weight of $35 \%$ as a factor of improving the company performance, we can conclude that implementation of the SCM processes allows improvement in the most important segment of the functioning of the analyzed pharmaceutical company. The results presented in Table 5 show that the least improvement was registered under the item customer satisfaction. This is due to the fact that the presented data were driven from the assessment of the activities after one year of the implementation of the SCM, while the relevant literature data for evaluation of SCM activities indicate that the assessment of the SCM could be obtained only after two years of its implementation. Further more the customers like end users need the longest period of time to note the improvement of the quality of performance of a particular company. The analysis shows that the implementation of SCM processes in the analyzed pharmaceutical company results with improvement of the final score for 1.09 percentage points with included percentage of importance/contribution. The operating profit of the company has increased for $3.1 \%$. This improvement was achieved only one year after the implementation of defined SCM processes.

\section{Conclusions}

The main benefits envisioned in the business case prior to the APS implementation were achieved. First the visibility and problem solving capabilities of the entire organization were improved by the use of a common data basis and a common visualization tool, allowing better and faster decisions; system based finite capacity scheduling and fast simulation capabilities improved the plan stability and resource utilization significantly; collaborative demand planning with the customers allow for a proactive stabilization of the demand as changes in the demand by the customers are compared with a constrained demand from the previous master planning. By reducing the order to cash cycle, as well as pushing for more collaboration with the affiliates through a VMI process, the inventory levels were reduced and significantly reduced the IT maintenance costs by consolidating the system landscape.

Standardization of the master data enable the visibility and interchangeability of information faster across the supply chain. The overall administrative workload for tasks performed previously manually or based on wrong information was reduced significantly.

\section{References}

Caillet, T., 2008. SCM in Pharmaceutical Company, in: Stadtler. H., Kilger. C., Supply Chain Management and Advanced Planning. Springer Berlin Heidelberg, pp. 415-430.

ISO 14001:2004. Enviromental management system Requirements with guidance for use. Available at: htpp:// www.iso.org/iso/home/standards/managment-standards/ iso $14000 . h$ tm

Mentzer, J.T., DeWitt, W., Keebler, K.S., Min, S., Nix. N.W., Smith. C.D., 2001. Defining Supply Chain Management. J. Business Logistics. 22(2), 1-25.

Peltz, E., 2008. Logistics: Supply based or Distribution Based? Army Logistician, Professional Bull. U.S. Army Logistics PB 700-07-02, 39(2).

Pharmaceutical supply chain initiative (PSCI), 2011. Pharmaceutical Industry Principles for Responsible Supply Chain Management, implementation guidance. Available at: http://www.pharmaceuticalsupplychain.org [Accessed 8 April 2015].

Rees. H., 2011. Supply Chain Management in the Drug Industry: Delivering Patient Value for pharmaceuticals and Biologics. Whiley \& Sons, Ltd.

\title{
Резиме
}

\section{Менаџирање со ланец на набавки во фармацевтска компанија (СЦМ), основни принципи и приказ на случај}

\author{
Зоран Наков ${ }^{1}$, Стевче Ацевски르, Рубинчо Зарески \\ ${ }^{1}$ Ново Нороиск Фарма ДООЕЛ, бул. Окииомвриска револуиија бр.18, 1000 Скойје, Р. Макеяонија \\ ${ }^{2}$ Алакалоия АД Скойје, бул. Алексаноар Макеоонски бр.12, 1000 Скойје, Р. Макеоонија \\ ${ }^{3}$ Фармаиевйски Факулиетеи Скойје, ул. Мајка Тереза бр.47, 1000 Скойје, Р. Макеоонија
}

Клучни зборови: Менаџирање со ланец на набавки (SCM), одговорен SCM, имплементација, евалуација

Supply Chain Management (Менаџирање со ланец на набавки) во фармацевтската индустрија се дефинира како „одговорен SCM“ и неговата имплементација е согласно принципите за бизнис етика, правата на работната сила и принципите на здрава и безбедна работна средина. Фармацевтските компании со имплементиран „одговорен

Макед. фарм. билт., 60 (2) 75 - 82 (2014) 
SCM“ треба да користат менаџмент системи со кои ќе се олесни континуираното подобрување во согласност со нивните работни принципи. Основна цел на овој менаџмент систем е да се обезбеди конзистентност, сигурност и континуирано подобрување на сите работни процеси во рамките на една организација.

Во презентираниот случај се објаснува проектот на Европска фармацевтска генеричка компанија, која има намера да имплементира најдобра пракса на SCM операции за пет Европски производни места и Европските логистички организации (снабдувачот на активната компонента, дистрибутивните центри, филијалите со нивните потрошувачи и други производители). Главна цел на проектната активност е создавање на идна посакувана и подобра То-Ве ситуација преку имплементација на нови и дефинирани SCM процесни активности кај постоечката То-Dау ситуација. 